\title{
Impact of triglycerides and waist circumference on insulin resistance and $\beta$ - cell function in non-diabetic first-degree relatives of type 2 diabetes
}

Fahd Ahmed, Molham AL-Habori ${ }^{*}$ Ebtesam Al-Zabedi and Riyadh Saif-Ali

\begin{abstract}
Background: Although there is abundant evidence indicating the relative contribution of insulin resistance (HOMAIR) and $\beta$-cell dysfunction (HOMA- $\beta$ ) among first-degree relatives (FDRs) of Type 2 DM patients, few studies reported the association between HOMA-IR and HOMA- $\beta$ with metabolic syndrome. Our objective was to evaluate the impact of metabolic syndrome factors on HOMA-IR, HOMA- $\beta$ and glycoproteins in non-diabetic FDRs.

Methods: In this study, 103 Yemeni male subjects aged $25-42$ years, with $\mathrm{BMl}<25 \mathrm{~kg} / \mathrm{m}^{2}$ were examined, 39 of whom were normal subjects with no family history of diabetes served as control and 64 subjects were non-diabetic FDRs of Type 2 DM patients.

Results: Both glycoproteins, glycated haemoglobin (HbA1c) and fructosamine as well as insulin, HOMA-IR and HOMA- $\beta$ were significantly $\left(p=4.9 \times 10^{-9} ; 6.0 \times 10^{-8} ; 6.6 \times 10^{-12} ; 1.3 \times 10^{-7} ; 5.5 \times 10^{-12}\right.$, respectively) higher in nondiabetic FDRs as compared to control group. Fasting plasma glucose, though within normal range, were significantly $(p=0.026)$ higher in non-diabetic FDRs. Linear regression analysis showed that both TG and WC are the main metabolic syndrome factors that significantly increased HOMA-IR $\left(B=0.334, p=1.97 \times 10^{-6} ; B=0.024, p=\right.$ $\left.1.05 \times 10^{-5}\right), \operatorname{HOMA}-\beta\left(B=16.8, p=6.8 \times 10^{-5} ; B=0.95, p=0.004\right)$, insulin $\left(B=16.5, p=1.2 \times 10^{-6} ; B=1.19, p=8.3 \times\right.$ $\left.10^{-6}\right)$ and $\mathrm{HbA1C}(\mathrm{B}=0.001, p=0.034 ; \mathrm{B}=0.007, p=0.037)$.

Conclusion: Triglyceride and WC are the important metabolic syndrome factors associated with insulin resistance, basal $\beta$-cell function and insulin levels in non-diabetic FDR men of Type 2 DM patients. Moreover, FDRs showed insulin resistance with compensatory $\beta$-cell function (hyperinsulinaemia) suggesting that insulin resistance precede the development of pancreatic $\beta$-cell dysfunction in individuals at risk of Type 2 DM.
\end{abstract}

Keywords: First-degree relatives of Type 2 DM, Insulin resistance, $\beta$-cell function, Metabolic syndrome, HbA1c, Fructosamine

\footnotetext{
* Correspondence: malhabori@hotmail.com

Department of Biochemistry and Molecular Biology, Faculty of Medicine and

Health Sciences, University of Sana'a, Sana'a, Republic of Yemen
}

(c) The Author(s). 2021 Open Access This article is licensed under a Creative Commons Attribution 4.0 International License, which permits use, sharing, adaptation, distribution and reproduction in any medium or format, as long as you give appropriate credit to the original author(s) and the source, provide a link to the Creative Commons licence, and indicate if changes were made. The images or other third party material in this article are included in the article's Creative Commons. licence, unless indicated otherwise in a credit line to the material. If material is not included in the article's Creative Commons licence and your intended use is not permitted by statutory regulation or exceeds the permitted use, you will need to obtain permission directly from the copyright holder. To view a copy of this licence, visit http://creativecommons.org/licenses/by/4.0/. The Creative Commons Public Domain Dedication waiver (http://creativecommons.org/publicdomain/zero/1.0/) applies to the data made available in this article, unless otherwise stated in a credit line to the data. 


\section{Background}

Type 2 Diabetes Mellitus (DM) is the predominant form of diabetes and accounts for approximately $90 \%$ of all diagnosed cases. A recent estimate by the International Diabetes Federation reported the global diabetes prevalence to be $9.3 \%$ (463 million) in 2019, rising to $10.9 \%$ (700 million) by 2045 [1]. Type 2 DM is a heterogeneous group of disorders that display relative insulin deficiency and is usually associated with obesity, insulin resistance, impaired insulin secretion, and increased hepatic glucose production [2]. Both genetic susceptibility and environmental factors likely contribute to the development of Type 2 DM [3]. In insulin-resistant states, pancreatic islets usually respond by increasing insulin secretion to maintain normoglycaemia, a process termed $\beta$-cell compensation. Individuals that are unable to sustain the $\beta$ cell compensatory response develops Type 2 DM. Longitudinal studies of individuals that developed Type 2 DM showed a rise in insulin levels in the normoglycaemic and pre-diabetic phases that maintain glycaemia near normal despite the presence of insulin resistance $(\beta$-cell compensation), followed by a decline in insulin levels ( $\beta$ cell dysfunction) when fasting glycaemia exceeds the upper limit of normal [4].

The specific etiologies of Type 2 DM are not known; however, the disease is associated with family history of diabetes, impaired glucose metabolism, obesity, physical inactivity, and ethnicity [3]. A family history of diabetes confers an up to threefold increased risk for first-degree relatives (FDRs) to develop diabetes [5]. The risk of developing Type $2 \mathrm{DM}$ is $40 \%$ for individuals who have one parent with Type $2 \mathrm{DM}$ and about $70 \%$ if both parents are affected [6]. A family history of diabetes has been shown to have a higher positive predictive value for diabetes than obesity [7]. Unlike diabetic patients, FDRs of diabetic patients do not display with signs of symptoms and their risk factors are often overlooked. Typical metabolic syndrome alterations have been reported at an early age, including central obesity, dyslipidemia, glucose intolerance, and high blood pressure $[8,9]$.

In FDRs, both insulin resistance and pancreatic $\beta$-cell dysfunction are inseparable phenomena and have been proposed to synergistically exacerbate type 2 diabetes and increase cardiometabolic risk [2, 10, 11]. During the past three decades, the relative contribution of insulin resistance and impaired $\beta$-cell function to Type 2 DM development has been the subject of many debates. Several prospective studies involving FDRs of Type $2 \mathrm{DM}$ in different ethnic groups have yielded different conclusions. Insulin resistance was reported to be an important risk factor for development of diabetes in Pima Indians [12], African-Americans [13], and Indians [14, 15]; while impaired $\beta$-cell function was suggested to have a more pronounced contribution to Type $2 \mathrm{DM}$ than insulin resistance in Caucasians [16, 17], Japan [18], Korea [19], and China [20, 21]. Meanwhile, others demonstrated both insulin resistance and impaired $\beta$-cell function had occurred in FDRs of type 2 DM patients before glucose tolerance was abnormal [22].

Although there is abundant evidence indicating the relative contribution of insulin resistance and $\beta$-cell dysfunction among FDRs of Type 2 DM patients, few studies reported the association between insulin resistance and $\beta$-cell dysfunction with metabolic syndrome. Therefore, the aim of this study was to evaluate the impact of metabolic syndrome risk factors on insulin resistance, $\beta$ cell function and glycated proteins.

\section{Methods}

\section{Study design, subjects and data collection}

This cross-sectional study was performed on 103 Yemeni male subjects aged 25-42 years, 64 were healthy non-diabetic FDRs of subjects with Type 2 DM patients who accompanied their diabetic patients during their routine visits to the Endocrine and Diabetic Clinic of AlThwara Hospital, Sana'a, and 39 were healthy control subjects with no family history of diabetes, who were on no medication that may affect blood glucose or lipid profile. A family history of diabetes was considered as the presence of diabetes in parents and/or siblings. All participants enrolled in this study were male to exclude the variation in insulin sensitivity during the menstrual cycle (whereby insulin sensitivity begins to decrease near ovulation and peaks during the luteal phase in premenopausal women without diabetes; and that estradiol and progesterone levels positively associated with measures of insulin sensitivity); as well as those with body mass index $(\mathrm{BMI})>25 \mathrm{~kg} / \mathrm{m}^{2}$ in order to avoid the influence of obesity on insulin resistance. Other exclusion criteria included those with diabetes, cardiac, renal, thyroid, liver diseases (which affects albumin metabolism and plasma glucose level), blood disorders (hemolytic anemia, iron deficiency anemia, anemia of chronic diseases and others) (which leads to incorrect glycated haemoglobin, $\left.\mathrm{HbA}_{1 \mathrm{C}}\right)$, and those with infections as well as smokers (which induces various cytokines and inflammatory mediators that affect insulin resistance). The study protocol was approved by the institutional review board (IRB) of the Faculty of Medicine and Health Sciences, Sana'a University. Informed consent was obtained from all participants after explaining the purpose and nature of the study.

Standard physical examinations including clinical variables were assessed as previously described [23]. The subject's height and weight were measured and body mass index (BMI), defined as weight in kilograms $(\mathrm{kg})$ divided by height in meters squared $\left(\mathrm{m}^{2}\right)$, was calculated. Waist circumference (WC) was measured midway 
between the lower rib margin and the superior iliac spine at the end of gentle expiration in a standing position. Blood pressure (BP) measurements were taken from each subject's right arm in the seated position by using an Omron IntelliSense automatic blood pressure monitor after $10 \mathrm{~min}$ of rest in a quiet room. Two to three successive BP readings were obtained at $5 \mathrm{~min}$ intervals and averaged. Normal glucose tolerance (NGT) was confirmed by fasting blood glucose (FBG) and HbA1c. Metabolic syndrome was classified according to the IDF criteria [24], defined by the presence of central obesity (WC in Asian male $\geq 90 \mathrm{~cm}$ ) together with two or more clinical features including raised triglyceride (TG), low HDL-cholesterol (HDL-c), high systolic blood pressure (SBP) and/or diastolic blood pressure (DBP), and raised FBG.

\section{Blood collection and biochemical analysis}

The following analysis was carried out as previously described [23]. A fasting venous blood $(5 \mathrm{ml})$ was collected from each subject after an overnight fast of more than $10 \mathrm{~h}$ and divided into two vacuum tubes; $4 \mathrm{ml}$ into plain tubes for biochemical assay and $1 \mathrm{ml}$ into $\mathrm{K}_{2}$ EDTA tube for $\mathrm{HbA1c}$ determination. The serum was separated within $30 \mathrm{~min}$ and stored at $-20^{\circ} \mathrm{C}$ for biochemical analysis. Haemolysate was prepared immediately for HbA1c determination within $2 \mathrm{~h}$ of blood collection. Serum TG, HDL-c, FBG and HbA1c were measured by chemistry autoanalyzer (Siemens Healthcare Diagnostics Inc., USA) using their respective kits. Fructosamine was measured spectrophotometrically (BioSystems, Spain). Insulin was measured by electrochemiluminescence immunoassay (ECL) on the Elecsys autoanalyzer (Roche Diagnostics, Germany). Insulin resistance (HOMA-IR) and $\beta$-cell function (HOMA- $\beta$ ) were calculated using the homeostasis model assessment (HOMA 2) calculator v2.2 which is available from Oxford Centre for Diabetes, Endocrinology and Metabolism.

\section{Statistical analysis}

The statistical analyses were performed on Statistical Package for the Social Sciences (SPSS) version 11.5 (SPSS Inc., Chicago, IL, USA). The sample size was calculated by "Real Statistics Resource Pack" added to excel. A medium effect size (0.35), power (0.8), 5 predicator (metabolic syndrome factors), and 0.05 significant levels was used. Data were log transformed because they were not normally distributed. These parameters means and 95\% confidence intervals were transformed back and reported as geometric means. The t-test was used for comparing the diabetic and metabolic syndrome parameter between normal subjects and FDRs of Type 2 DM. The impact of metabolic syndrome factors on diabetic parameters among FDRs of Type 2 DM was assisted by multiple linear-regression (enter method) controlled for age. The correlation was done between all parameters to screen the cofactor parameters to be included in multiple linear regression analysis. Significant differences were indicated if $p$-value was $<0.05$.

\section{Results}

Table 1 shows the baseline characteristics of the nondiabetic FDRs and control group. Body mass index, WC, SBP and DBP were significantly $(p=0.0004, p=2.4 \times$ $10^{-5}, p=0.038, p=0.009$ ) higher in non-diabetic FDRs by $8,9.3,4.5$ and $5.5 \%$, respectively as compared to control group. Plasma TG was significantly $\left(p=8.6 \times 10^{-7}\right)$ higher in non-diabetic FDRs than that of the control group by $51.2 \%$; whereas plasma HDL-c was border-line significantly $(p=0.089)$ lower in non-diabetic FDRs by $6.1 \%$. Along the same line, FBG, HbA1c and fructosamine were significantly $\left(p=0.026 ; p=4.9 \times 10^{-9}, p=\right.$ $6.0 \times 10^{-8}$ ) higher in non-diabetic FDRs by 4,6 and $19.4 \%$, respectively with respect to control group. Plasma insulin levels, HOMA-IR and HOMA- $\beta$ were significantly $\left(p=6.6 \times 10^{-12}, p=5.5 \times 10^{-12}, p=1.3 \times 10^{-7}\right)$ higher in non-diabetic FDRs by $87.3,87.5,37.7 \%$ as compared with the control group.

The correlation between metabolic syndrome factors and diabetic parameters is depicted in Table 2. Triglyceride and WC showed positive correlation with HbA1c, insulin, HOMA-IR and HOMA- $\beta$. Moreover, WC was positively correlated with FBG. Diastolic blood pressure, however, was positively correlated with insulin, HOMAIR and border-line associated with HOMA- $\beta$. Unlike HbA1c, fructosamine levels did not show a correlation with any of the metabolic syndrome factors. Therefore, fructosamine, HDL-c and SBP were not included in the following linear regression analysis.

Table 3 shows the linear regression analysis of the impact of metabolic syndrome risk factors on diabetic parameters among FDRs of Type 2 DM. Both TG and WC significantly affected insulin levels, HOMA-IR, HOMA- $\beta$ and HbA1c. In contrast, DBP had no effect on diabetic parameters.

\section{Discussion}

The results presented in this study showed that TG and WC are the main metabolic syndrome factors that increased insulin resistance, $\beta$-cell function, insulin and HbA1c in non-diabetic FDRs of Type 2 DM. A recent study in healthy male adolescents with parental history of Type 2 DM demonstrated that elevated TG level and WC influenced the risk of insulin resistance [25]. Moreover, TG and WC were recently demonstrated to be associated with insulin resistance [26-29], with $75 \%$ of insulin resistance being attributed to the TG level and the association was significant even when TG was in the 
Table 1 Baseline characteristics of normal subjects and non-diabetic first degree relatives of Type 2 DM patients

\begin{tabular}{|c|c|c|c|}
\hline & $\begin{array}{l}\text { Normal subjects } \\
(n=39)\end{array}$ & $\begin{array}{l}\text { FDRs of Type } 2 \text { DM } \\
(n=64)\end{array}$ & $p$-value \\
\hline Age (years) & $31.4 \pm 4.61$ & $32.3 \pm 5.16$ & 0.373 \\
\hline Body mass index $\left(\mathrm{kg} / \mathrm{m}^{2}\right)$ & $21.2 \pm 2.52$ & $22.9 \pm 2.11$ & 0.0004 \\
\hline Waist Circumference (cm) & $80.9 \pm 7.94$ & $88.4 \pm 9.2$ & $2.4 \times 10^{-5}$ \\
\hline Systolic blood pressure $(\mathrm{mmHg})$ & $112 \pm 11$ & $117 \pm 11$ & 0.038 \\
\hline Diastolic blood pressure $(\mathrm{mmHg})$ & $73 \pm 8$ & $77 \pm 8$ & 0.009 \\
\hline Triglycerides (mmol/l) & $1.31 \pm 0.53$ & $1.98 \pm 0.76$ & $8.6 \times 10^{-7}$ \\
\hline HDL-cholesterol (mmol/l) & $1.15 \pm 0.22$ & $1.08 \pm 0.19$ & 0.089 \\
\hline Fasting blood glucose $(\mathrm{mmol} / \mathrm{l})$ & $4.99 \pm 0.34$ & $5.19 \pm 0.47$ & 0.026 \\
\hline Glycated hemoglobin (\%) & $5.0 \pm 0.20$ & $5.3 \pm 0.28$ & $4.9 \times 10^{-9}$ \\
\hline Fructosamine $(\mathrm{mmol} / \mathrm{l})$ & $248 \pm 39.0$ & $296 \pm 41.6$ & $6.0 \times 10^{-8}$ \\
\hline Insulin (pmol/l) & $38 \pm 13.70$ & $71.1 \pm 28.60$ & $6.6 \times 10^{-12}$ \\
\hline HOMA-IR & $0.8 \pm 0.26$ & $1.5 \pm 0.60$ & $5.5 \times 10^{-12}$ \\
\hline HOMA- $\beta$ & $85 \pm 24$ & $117 \pm 33$ & $1.3 \times 10^{-7}$ \\
\hline
\end{tabular}

Data are presented as means \pm SD. Mean significant difference $p<0.05$ bolded HOMA-IR insulin resistance, HOMA- $\beta \beta$-cell function

normal range, and $81.5 \mathrm{mg} / \mathrm{dL}$ was proposed to be the cut-off value of TG to predict the occurrence of insulin resistance [26]. Several early studies also showed insulin resistance to correlate well with TG levels [30, 31], and a dose-response relationship between serum TG and insulin resistance has been demonstrated [32]. Triglyceride was also reported to be an independent risk factor for insulin resistance and diabetes [27, 33] and an independent positive predictor of worsening insulin resistance and incident diabetes [34]. Elevated TG precedes impaired glucose regulation and that utilization of TG may identify individuals at high risk of incident diabetes earlier than standard glucose screening [35]. Similarly, WC was suggested to be used as a predictor of insulin resistance [28, 29, 36] with a cutoff value of $89.5 \mathrm{~cm}$ [37]; and that increased HOMA-IR was observed in subjects of normal BMI/high WC group [38]. Moreover, several studies showed that TyG index, a product of triglycerides and glucose, as well as TyG-related parameters that combined obesity indices and TyG index, such as TyGBMI or TyG-WC, can predict insulin resistance [39-41] and be an early marker for detecting the risks of prediabetes and diabetes in FDRs of Type 2 DM [40].

Visceral (intra-abdominal) fat deposits are recognized to play a more important roles in the development of insulin resistance, because they produce more fatty acids and secrete inflammatory cytokines and adipokines [40, 42, 43]. Many studies have confirmed that higher levels of TG in the liver and muscle may disrupt glucose metabolism by increasing free fatty acids (FFA) and its flux from adipose to non-adipose tissue [44, 45]. It also limits insulin-stimulated glucose utilization by increasing fatty acid oxidation leading to a decreased synthesis of hepatic glycogen and reduced muscle glucose uptake [46]. Moreover, hypertriglyceridemia was reported to diminish glucose stimulated insulin secretion by inhibiting glucose oxidation via reducing pyruvate dehydrogenase $(\mathrm{PDH})$ activity and elevating PDH kinase activity [47].

Several studies, in both humans and animal models, showed increased TG levels were associated with increased $\beta$-cell function $[48,49]$, and recent evidence showed TG to correlate with $\beta$-cell function in non-

Table 2 Correlation of metabolic syndrome factors with diabetic parameters among FDRs of Type 2 DM

\begin{tabular}{|c|c|c|c|c|c|c|}
\hline & FBG & HbA1c & Fructosamine & Insulin & HOMA-IR & HOMA- $\beta$ \\
\hline Age & $0.15(0.12)$ & $0.25(0.01)$ & $0.14(0.16)$ & $-0.05(0.60)$ & $-0.05(0.61)$ & $-0.13(0.19)$ \\
\hline Waist Circumference & $0.26(0.009)$ & $0.27(0.007)$ & $0.11(0.25)$ & $0.50\left(6.5 \times 10^{-8}\right)$ & $0.50\left(8.6 \times 10^{-8}\right)$ & $0.38\left(9 \times 10^{-5}\right)$ \\
\hline Triglyceride & $0.1(0.60)$ & $0.2(0.02)$ & $0.2(0.07)$ & $0.5\left(4.7 \times 10^{-9}\right)$ & $0.5\left(7.4 \times 10^{-9}\right)$ & $0.5\left(3.2 \times 10^{-7}\right)$ \\
\hline Systolic Blood Pressure & $0.11(0.27)$ & $0.15(0.14)$ & $0.05(0.64)$ & $0.13(0.20)$ & $0.13(0.17)$ & $0.06(0.52)$ \\
\hline Diastolic Blood Pressure & $0.05(0.64)$ & $0.10(0.30)$ & $0.04(0.71)$ & $0.23(0.02)$ & $0.24(0.02)$ & $0.19(0.05)$ \\
\hline HDL-Cholesterol & $0.076(0.45)$ & $0.001(1.0)$ & $-0.046(0.65)$ & $-0.149(0.13)$ & $-0.145(0.14)$ & $-0.180(0.07)$ \\
\hline
\end{tabular}

Data are presented as $\mathrm{R}^{2}$ and ( $p$-value)

FBG fasting blood glucose, $H b A 1 c$ glycated hemoglobin, HOMA-IR insulin resistance, HOMA- $\beta$-cell function 
Table 3 Impact of metabolic syndrome factors on diabetic parameters among FDRs of Type 2 DM

\begin{tabular}{|c|c|c|c|c|}
\hline & HbA1c & Insulin & HOMA-IR & HOMA- $\beta$ \\
\hline Triglyceride & $\begin{array}{l}0.001 \\
(\mathbf{0 . 0 3 4 )}\end{array}$ & $\begin{array}{l}16.5 \\
\left(1.2 \times 10^{-6}\right)\end{array}$ & $\begin{array}{l}0.334 \\
\left(1.97 \times 10^{-6}\right)\end{array}$ & $\begin{array}{l}16.8 \\
\left(6.9 \times 10^{-5}\right)\end{array}$ \\
\hline Waist Circumference & $\begin{array}{l}0.007 \\
(\mathbf{0 . 0 3 7 )}\end{array}$ & $\begin{array}{l}1.19 \\
\left(8.3 \times 10^{-6}\right)\end{array}$ & $\begin{array}{l}0.024 \\
\left(1.05 \times 10^{-5}\right)\end{array}$ & $\begin{array}{l}0.95 \\
\mathbf{( 0 . 0 0 4 )}\end{array}$ \\
\hline Diastolic Blood Pressure & $\begin{array}{l}-0.001 \\
(0.814)\end{array}$ & $\begin{array}{l}0.31 \\
(0.284)\end{array}$ & $\begin{array}{l}0.007 \\
(0.273)\end{array}$ & $\begin{array}{l}0.364 \\
(0.322)\end{array}$ \\
\hline
\end{tabular}

Analyzed by linear regression controlled for age and HDL-c, the results are presented as B value and ( $p$ value)

$H b A 1 c$ glycated hemoglobin, HOMA-IR insulin resistance, HOMA- $\beta \beta$-cell function

diabetic individuals [50] indicating the existence of severe insulin resistance and impaired $\beta$-cell compensatory response to insulin resistance. Moreover, in NGT subjects hypertriglyceridaemia was reported to be associated with increased insulin resistance and overstimulation of $\beta$-cell function [51]. Elevated TG levels in obese FDRs exhibited increased $\beta$-cell function, suggesting that serum TG is a good indicator of $\beta$-cell function in the newly characterized obese FDRs with NGT [52]. Earlier studies have also reported that impaired $\beta$-cell function caused by dyslipidemia precedes the manifestation of Type 2 DM [40, 53, 54].

Our results also revealed that non-diabetic FDRs of Type $2 \mathrm{DM}$ patients to have insulin resistance and no signs of impaired $\beta$-cell function as reflected by the significantly higher HOMA-IR (87.5\%) and HOMA- $\beta$ (37.7\%) with respect to the control subjects; suggesting that insulin resistance precedes the development of pancreatic $\beta$ cell dysfunction in individuals at risk of developing Type 2 DM. This is in agreement with several studies showing insulin resistance to precede the development of $\beta$-cell dysfunction [14, 15, 55, 56]. Moreover, results from a population-based prospective study in South Asian, showed that impaired glucose tolerance occurred 3-5 years after insulin sensitivity significantly decreased, whereas $\beta$-cell function remained unchanged during this period, signifying that insulin resistance may be the determinant factor in the progression of NGT to prediabetes [57]. A recent study in middle-aged and elderly Chinese population further supports that insulin resistance and $\beta$ cell dysfunction are the main determinants of developing prediabetes and Type 2 DM [58].

Insulin resistance preceding the development of $\beta$-cell dysfunction has been associated with more prevalent cardiometabolic disorders such as obesity, dyslipidemia, and hypertension [59] through mechanisms including low-grade inflammation, modifying lipoprotein particles, and impairing endothelial function [11]. Studies have also demonstrated that $\beta$-cell function could remain stable or exhibit high activity in obese individuals, mainly due to the $\beta$-cell compensation in response to insulin resistance $[60,61]$. But the $\beta$-cell compensation may hit the limit with the continued deterioration of insulin resistance [62]. In contrast, several studies reported the degree of insulin resistance in FDRs to be similar to that of the newly diagnosed Type 2 DM, suggesting that progression from NGT to Type 2 DM in the non-obese FDRs was not attributed to the worsening of insulin resistance but to deterioration of $\beta$-cell function over time as the primary pathology $[19,21,63-65]$. This progressive deterioration in $\beta$-cell function was associated with a progressive increase in FFA and insulin resistance in adipose tissue [66].

Our results also showed non-diabetic FDRs of Type 2 DM patients to have significantly higher insulin levels with normoglycaemic levels, which are in agreement with earlier studies $[9,54,67]$ showing ethnic groups with high susceptibility for Type $2 \mathrm{DM}$ are prominently hyperinsulinemic with fasting glucose within the normal range $[56,68]$. The observed plasma glucose, though within the normal range, were significantly higher in non-diabetic FDRs which is in support of earlier studies reporting FDRs of Type $2 \mathrm{DM}$ to be at increased risk of developing hyperglycemia [14, 15, 69]. Thus as glucose tolerance gradually worsened in FDRs, the insulin levels and insulin resistance were also observed to rise progressively following the natural pathway of the disease $[15$, 70]. Moreover, Individuals with a family history of Type 2 DM showed higher plasma TG levels which are in agreement with several studies showing FDRs to have insulin resistance and dyslipidemia [15, 71, 72]. Higher prevalence of metabolic syndrome were also reported in FDRs as compared to those without a family history despite of normoglycemia [26, 73], and that hyperlipidaemic subjects were 3-times higher at risk of developing Type 2 DM [74].

Our results also showed plasma $\mathrm{HbA}_{1 \mathrm{C}}$ and fructosamine levels to be significantly higher in non-diabetic FDRs; which are in agreement with several studies [14, $15,75]$. The significant aspect of this increase was that it occurred within normal ranges of glucose concentrations. Our results also showed a significant correlation between HbA1c and HOMA-IR, which is in line with an earlier study [76] suggesting that HbA1c could be a marker not just for hyperglycaemia, but also for detection of insulin resistance. Different HbA1c cut-off values 
have been reported for diagnosing pre-diabetes and diabetes in different ethnic groups [77, 78]. Previous findings demonstrated that $\mathrm{HbA}_{1 \mathrm{C}}$ of 5.7 to 6.2 (upper tertile) was associated with reduced insulin action among non-diabetic, obese, FDRs of African-Americans who are genetically predisposed to Type 2 DM [79]. Moreover, $\mathrm{HbA}_{1 \mathrm{C}}$ of $5.45 \%$ was suggested to act as a predictive measure of impaired fasting glucose and metabolic syndrome as well as cardiovascular risk factors in the Korean population [76]. In addition, individuals with higher baseline $\mathrm{HbA}_{1 \mathrm{C}}$ values $(\geq 5.8 \%)$ were reported to be at significantly higher risk for progression to impaired glucose tolerance and Type 2 DM [80-82].

Our study has some limitations. First, although the homeostasis model assessment of insulin resistance (HOMA-IR) has proved to be an essential tool for the surrogate assessment of insulin resistance, there is evident variability in the threshold levels of HOMA-IR to define insulin resistance. Second, HOMA- $\beta$ is an indirect measure of $\beta$-cell function and only takes into account fasting/basal plasma glucose and insulin concentrations, thus generating limited information about the daily fluctuations in glucose homeostasis, and the impact of several common anti-diabetes treatments on either $\beta$-cell function or tissue insulin sensitivity. Third, all participants enrolled in this study were only male. Fourth, recall and misclassification biases may have affected our results, because the family history of diabetes data was obtained from participants by interviewers using questionnaires. Fifth, because our study sample consists mainly of Yemenis, the results cannot be generalized to other ethnicities.

\section{Conclusion}

The results presented in this study showed that TG and WC are the main metabolic syndrome factors associated with insulin resistance, basal $\beta$-cell function, insulin and HbA1c in non-diabetic FDR men of Type 2 DM. Moreover, non-diabetic FDRs of Type 2 DM patients have insulin resistance with compensatory $\beta$-cell function (hyperinsulinaemia) suggesting that insulin resistance precedes the development of pancreatic $\beta$-cell dysfunction in individuals at risk of developing Type 2 DM. Our results also showed that metabolic syndrome may occur more frequently in non-diabetic FDRs and together with the existing insulin resistance and hyperinsulinaemia may participate in the development of $\beta$-cell dysfunction and the subsequent onset of diabetes.

\section{Abbreviations}

BMl: Body mass index; BP: Blood pressure; DBP: Diastolic blood pressure; ECl: Electrochemiluminescence immunoassay; FBG: Fasting blood glucose; FDRs: First degree relatives; FFA: Free fatty acid; HbA1c: Glycated haemoglobin; HDL-c: High-density lipoprotein cholesterol; HOMA- $\beta$ : $\beta$-cell function; HOMA-IR: Insulin resistance; NGT: Normal glucose tolerance;
SBP: Systolic blood pressure; SD: Standard deviation; SPSS: Statistical Package for Social Sciences; TG: Triglyceride; WC: Waist circumference

Acknowledgements

The authors thank all the study participants.

\section{Authors' contributions}

MA designed the study, participated in the interpretation of data, wrote the manuscript and gave the final approval of the version to be published. RS participated in the analysis, interpretation of data and revised manuscript. FA collected the samples and carried out the biochemical analysis. EA assisted in the biochemical analysis. All authors read and approved the final manuscript.

\section{Funding}

Not Applicable.

\section{Availability of data and materials}

The data set generated and/or analyzed during this study are included in this submitted manuscript and is available from the corresponding author on reasonable request.

\section{Declarations}

\section{Ethics approval}

This study was conducted in accordance with the Declaration of Helsinki. All the recruited participants have provided written informed consent before the investigation. The study protocol was approved by the institutional review board (IRB) of the Faculty of Medicine and Health Sciences, Sana'a University.

\section{Consent for Publication}

Not Applicable.

\section{Competing interests}

The authors have no conflict of interest to declare.

Received: 26 February 2021 Accepted: 10 May 2021

Published online: 16 June 2021

\section{References}

1. International Diabetes Federation. IDF diabetes atlas. 9th ed. Brussels, Belgium: International Diabetes Federation; 2019

2. Kahn SE, Cooper ME, Del Prato S. Pathophysiology and treatment of type 2 diabetes: perspectives on the past, present, and future. Lancet. 2014; 383(9922):1068-83.

3. Norris SL, Kansagara D, Bougatsos C, Nygren P, Fu R. Screening for type 2 diabetes mellitus: update of 2003 systematic evidence review for the U.S. Preventive Services Task Force. AHRQ Publication No. 08-05116-EF-1, pp. 147; 2008.

4. Leahy JL. Pathogenesis of type 2 diabetes mellitus. Arch Med Res. 2005;36: 197-209.

5. Wagner R, Thorand B, Osterhoff MA, Muller G, Bohm A, Meisinger C, et al. Family history of diabetes is associated with higher risk for prediabetes: a multicentre analysis from the German Center for Diabetes Research. Diabetologia. 2013;56(10):2176-80.

6. Ahlqvist E, Ahluwalia TS, Groop L. Genetics of type 2 diabetes. Clin Chem. 2011;57(2):241-54

7. Hariri S, Yoon PW, Moonesinghe R, Valdez R, Khoury MJ. Evaluation of family history as a risk factor and screening tool for detecting undiagnosed diabetes in a nationally representative survey population. Genet Med. 2006; 8:752-9.

8. Muktabhant B, Sanchaisuriya P, Trakulwong M, Mingchai R, Schelp FP. A first degree relative with diabetes mellitus is an important risk factor for rural Thai villagers to develop type 2 diabetes mellitus. Asia Pac J Public Health. 2015:27(4):385-93.

9. Kumar A, Tewari P, Sahoo SS, Srivastava AK. Prevalence of insulin resistance in first degree relatives of Type-2 Diabetes mellitus patients: a prospective study in north India population. Indian J Clin Biochem. 2005;20(2):10-7.

10. Shulman Gl. Ectopic fat in insulin resistance, dyslipidemia, and cardiometabolic disease. N Engl J Med. 2014;371(23):2237-8. 
11. Laakso M, Kuusisto J. Insulin resistance and hyperglycaemia in cardiovascular disease development. Nat Rev Endocrinol. 2014;10(5):293-302.

12. Weyer C, Bogardus C, Mott DM, Pratley RE. The natural history of insulin secretory dysfunction and insulin resistance in the pathogenesis of type 2 diabetes mellitus. J Clin Invest. 1999;104:787-94.

13. Osei K, Rhinesmith S, Gaillard T, Schuster D. Impaired insulin sensitivity, insulin secretion, and glucose effectiveness predict future development of impaired glucose tolerance and type 2 diabetes in pre-diabetic African Americans: implications for primary diabetes prevention. Diabetes Care. 2004;27:1439-46

14. Sathiyapriya V, Bobby Z, Agrawal A, Selvaraj N. Protein glycation, insulin sensitivity and pancreatic beta-cell function in high-risk, non-diabetic, firstdegree relatives of patients with type 2 diabetes. Indian J Physiol Pharmacol. 2009;53(2):163-8.

15. Usgaokari AP, Dhume CY, Amonkar SD. Comparative assessment of insulin sensitivity and pancreatic beta cell function in diabetics and non-diabetics. Int J Pharma Bio Sci. 2012;3(1):405-13.

16. Pimenta W, Korytkowski M, Mitrakou A, Jenssen T, Yki-Jarvinen H, Evron W, et al. Pancreatic beta-cell dysfunction as the primary genetic lesion in NIDD M. Evidence from studies in normal glucose-tolerant individuals with a firstdegree NIDDM relative. JAMA. 1995;273:1855-61.

17. Bonadonna RC, Stumvoll M, Fritsche A, Muggeo M, Haring H, Bonora E, et al. Altered homeostatic adaptation of first and second-phase beta-cell secretion in the offspring of patients with type 2 diabetes: studies with a minimal model to assess beta-cell function. Diabetes. 2003;52:470-80.

18. Fukushima M, Usami M, Ikeda M, Nakai Y, Taniguchi A, Matsuura T, et al. Insulin secretion and insulin sensitivity at different stages of glucose tolerance: a cross-sectional study of Japanese type 2 diabetes. Metabolism. 2004;53:831-5

19. Rhee SY, Kwon MK, Park BJ, Chon S, Jeong IK, Oh S, et al. Differences in insulin sensitivity and secretory capacity based on OGTT in subjects with impaired glucose regulation. Korean J Intern Med. 2007;22:270-4.

20. Liu J, Li YB, Shao H, Li YX, Yuan YH, Xiao YB, et al. Evaluation of islet beta cell function in subjects with normal glucose tolerance, impaired glucose regulation, and type 2 diabetes mellitus. Zhonghua Yi Xue Za Zhi. 2007;15: 1252-5.

21. Qian L, Xu L, Wang X, Fu X, Gu Y, Lin F, et al. Early insulin secretion failure leads to diabetes in Chinese subjects with impaired glucose regulation. Diabetes Metab Res Rev. 2009;25:144-9.

22. Han XY, Ji LN, Zhou XH. Cross-sectional study of the pathophysiologic and clinical features in the first-degree relatives of type 2 diabetic patients. Beijing Da Xue Xue Bao. 2005;37:159-62.

23. Mohammed M, AL-Habori M, Abdullateef A, Saif-Ali R. Impact of metabolic syndrome factors on testosterone and SHBG in type 2 diabetes mellitus and metabolic syndrome. J Diabetes Res. 2018;2018:4926789.

24. Zimmet P, Magliano D, Matsuzawa Y, Alberti G, Shaw J. The metabolic syndrome: a global public health problem and a new definition. $J$ Atheroscler Thromb. 2005;12(6):295-300

25. Makbul Aman A, Rasyid H, Bakri S, Patellongi IJ. The association between parents history of Type 2 diabetes with metabolic syndrome component and insulin resistance in non-diabetic young adult male. Acta Med Indones. 2018;50(4):309-13.

26. Bi C, Wang L, Sun C, Sun M, Zheng P, Xue Z, et al. Association between normal triglyceride and insulin resistance in US adults without other risk factors: a cross-sectional study from the US National Health and Nutrition Examination Survey, 2007-2014. BMJ Open. 2019;9:e028652.

27. Zhao J, Zhang Y, Wei F, Song J, Cao Z, Chen C, et al. Triglyceride is an independent predictor of type 2 diabetes among middle-aged and older adults: a prospective study with 8-year follow-ups in two cohorts. J Transl Med. 2019;17:403.

28. Cheng Y-H, Tsao Y-C, Tzeng I-S, Chuang H-H, Li W-C, Tung T-H, et al. Body mass index and waist circumference are better predictors of insulin resistance than total body fat percentage in middle-aged and elderly Taiwanese. Medicine. 2017;96(39):e8126.

29. Fu S, Lin $Y$, Ping $P$, Luo L, Ye P. Overall obesity had similar ability to identify the insulin resistance and pancreatic $\beta$-cell function compared with abdominal obesity in Chinese community-dwelling population without type 2 diabetes. Int J Clin Exp Med. 2017;10(3):5293-9.

30. Jeong SU, Kang DG, Lee DH, Lee KW, Lim DM, Kim BJ, et al. Clinical characteristics of Type 2 Diabetes patients according to family history of diabetes. Korean Diabetes J. 2010;34:222-8.
31. Irace C, Carallo C, Scavelli FB, De Franceschi MS, Esposito T, Tripolino C, et al Markers of insulin resistance and carotid atherosclerosis: a comparison of the homeostasis model assessment and triglyceride glucose index. Int J Clin Pract. 2013:67:665-72.

32. Moro E, Gallina P, Pais M, Cazzolato G, Alessandrini P, Bittolo-Bon G. Hypertriglyceridemia is associated with increased insulin resistance in subjects with normal glucose tolerance: evaluation in a large cohort of subjects assessed with the 1999 World Health Organization criteria for the classification of diabetes. Metabolism. 2003;52(5):616-9.

33. Ginsberg HN, Zhang Y-L, Hernandez-Ono A. Regulation of plasma triglycerides in insulin resistance and diabetes. Arch Med Res. 2005;36(3): 232-40

34. Riediger ND, Clark K, Lukianchuk V, Roulette J, Bruce S. Fasting triglycerides as a predictor of incident diabetes, insulin resistance and $\beta$-cell function in a Canadian First Nation. Int J Circumpolar Health. 2017;76(1):1310444.

35. Olafsdottir E, Aspelund T, Sigurdsson G, Thorsson B, Benediktsson R, Harris TB, et al. Unfavourable risk factors for type 2 diabetes mellitus are already apparent more than a decade before onset in a population-based study of older persons: from the Age, Gene/Environment Susceptibility-Reykjavik Study (AGES-Reykjavik). Eur J Epidemiol. 2009;24(6):307-14.

36. González-Jiménez E, Schmidt-RioValle J, Montero-Alonso MA, Padez C, Garcia-Garcia CJ, Perona JS. Influence of biochemical and anthropometric factors on the presence of insulin resistance in adolescents. Biol Res Nurs. 2016:18:541-8.

37. Wahrenberg H, Hertel K, Leijonhufvud BM, Persson L-G, Toft E, Amer P. Use of waist circumference to predict insulin resistance: retrospective study. BMJ. 2005:330:1363-4.

38. Sasaki R, Yano Y, Yasuma T, Onishi Y, Suzuki T, Maruyama-Furuta N, et al. Association of waist circumference and body fat weight with insulin resistance in male subjects with normal body mass index and normal glucose tolerance. Intern Med. 2016;55:1425-32.

39. Er LK, Wu S, Chou HH, Hsu LA, Teng MS, Sun YC, et al. Triglyceride glucosebody mass index is a simple and clinically useful surrogate marker for insulin resistance in nondiabetic individuals. PLOS One. 2016:11:e0149731.

40. Zheng S, Shi S, Ren X, Han T, Li Y, Chen Y, et al. Triglyceride glucose-waist circumference, a novel and effective predictor of diabetes in first-degree relatives of type 2 diabetes patients: cross-sectional and prospective cohort study. J Transl Med. 2016;14:260.

41. Lim J, Kim J, Koo SH, Kwon GC. Comparison of triglyceride glucose index, and related parameters to predict insulin resistance in Korean adults: an analysis of the 2007-2010 Korean National Health and Nutrition Examination Survey. PLoS One. 2019;14(3):e0212963.

42. Boden G, Shulman Gl. Free fatty acids in obesity and type 2 diabetes: defining their role in the development of insulin resistance and beta-cell dysfunction. Eur J Clin Investig. 2002;32(S3):14-23.

43. Kwon $\mathrm{H}$, Pessin JE. Adipokines mediate inflammation and insulin resistance. Front Endocrinol. 2013:4:71.

44. Nagle CA, Klett EL, Coleman RA. Hepatic triacylglycerol accumulation and insulin resistance. J Lipid Res. 2009:50:574-9.

45. Parhofer KG. Interaction between glucose and lipid metabolism: more than diabetic dyslipidemia. Diabetes Metab J. 2015;39(5):353e62.

46. Samuel VT, Shulman Gl. The pathogenesis of insulin resistance: integrating signaling pathways and substrate flux. J Clin Invest. 2016;126(1):12-22.

47. Zhou YP, Berggren PO, Grill V. A fatty acid-induced decrease in pyruvate dehydrogenase activity is an important determinant of beta-cell dysfunction in the obese diabetic db/db mouse. Diabetes. 1996:45(5):580-6.

48. Bardini G, Rotella CM, Giannini S. Dyslipidemia and diabetes: reciprocal impact of impaired lipid metabolism and beta-cell dysfunction on microand macrovascular complications. Rev Diabetes Stud. 2012;9:82-93.

49. Zheng T, Gao Y, Tian H. Relationship between blood lipid profiles and pancreatic islet beta cell function in Chinese men and women with normal glucose tolerance: a cross sectional study. BMC Public Health. 2012;12:634.

50. Zheng S, Xu H, Zhou H, Ren X, Han T, Chen Y, et al. Associations of lipid profiles with insulin resistance and $\beta$ cell function in adults with normal glucose tolerance and different categories of impaired glucose regulation. PLoS One. 2017;12(2):e0172221.

51. Bardini G, Dicembrini I, Pala L, Cresci B, Rotella CM. Hypertriglyceridaemic waist phenotype and beta-cell function in subjects with normal and impaired glucose tolerance. Diabet Med. 2011;28:1229-33.

52. Torres-Rasgado E, Porchia LM, Ruiz-Vivanco G, Gonzalez-Mejia ME, BáezDuarte BG, Pulido-Pérez $P$, et al. Obese first-degree relatives of patients with 
type 2 diabetes with elevated triglyceride levels exhibit increased $\beta$-cell function. Metab Syndr Relat Disord. 2015;13(1):45-51.

53. Zheng S, Zhou H, Han T, Li Y, Zhang Y, Liu W, et al. Clinical characteristics and beta cell function in Chinese patients with newly diagnosed type 2 diabetes mellitus with different levels of serum triglyceride. BMC Endocr Disord. 2015;15:21.

54. Brunisholz KD, Joy EA, Hashibe M, Gren LH, Savitz LA, Hamilton S, et al. Incidental risk of type 2 diabetes mellitus among patients with confirmed and unconfirmed prediabetes. PLoS One. 2016;11(7):e0157729.

55. Praveen EP, Sahoo J, Khurana ML, Kulshreshtha B, Khadgawat R, Gupta N, et al. Insulin sensitivity and beta-cell function in normoglycemic offspring of individuals with type 2 diabetes mellitus: impact of line of inheritance. Indian J Endocrinol Metab. 2012;16(1):105-11.

56. Sharma VK, Nandeesha H, Vinod KV, Subramanian SK, Sankar DS, Rajendran R. Comparison of anthropometric, cardiovascular, autonomic, baroreflex sensitivity, aerobic fitness, inflammatory markers and oxidative stress parameters between first degree relatives of diabetes and controls. Diabetes Metab Syndr Clin Res Rev. 2019;13(1):652-8.

57. Hulman A, Simmons RK, Brunner EJ, Witte DR, Faerch K, Vistisen D, et al. Trajectories of glycaemia, insulin sensitivity and insulin secretion in South Asian and white individuals before diagnosis of type 2 diabetes: a longitudinal analysis from the Whitehall II cohort study. Diabetologia. 2017; 60:1252-60.

58. Cai X, Xia L, Pan Y, He D, Zhu H, Wei T, et al. Differential role of insulin resistance and $\beta$-cell function in the development of prediabetes and diabetes in middle-aged and elderly Chinese population. Diabetol Metab Syndr. 2019;11:24.

59. Wang T, Zhao Z, Xu Y, Qi L, Xu M, Lu J, et al. Insulin resistance and $\beta$-Cell dysfunction in relation to cardiometabolic risk patterns. J Clin Endocrinol Metab. 2018;103(6):2207-15.

60. Yoon KH, Ko SH, Cho JH, Lee JM, Ahn YB, Song KH, et al. Selective beta-cell loss and alpha-cell expansion in patients with type 2 diabetes mellitus in Korea. J Clin Endocrinol Metab. 2003;88(5):2300-8.

61. Funakoshi S, Fujimoto S, Hamasaki A, Fujiwara H, Fujita $Y$, Ikeda $K$, et al. Analysis of factors influencing pancreatic beta-cell function in Japanese patients with type 2 diabetes: association with body mass index and duration of diabetic exposure. Diabetes Res Clin Pract. 2008;82(3):353-8.

62. Sun $M$, Huang $X$, Jiang $L$, Yan $Y$, Li B, Zhong $W$, et al. Characterization of bcell function and insulin resistance in overweight Chinese adolescents with normal glucose tolerance. Exp Ther Med. 2013;6(2):547-51.

63. Cnop M, Schraw T, Vidal J, Scherer PE, Hull RL, Boyko EJ, et al. Progressive loss of $\beta$-cell function leads to worsening glucose tolerance in first-degree relatives of subjects with Type 2 Diabetes. Diabetes Care. 2007;30:677-82.

64. Wang C, Tan H, Yu H, Zhang X, Suo L, Lu Z, et al. Impairment of insulin action in non-obese, normal-glucose tolerant, first-degree relatives of Chinese type 2 diabetic patients. Diabetes Res Clin Pract. 2011;91:67-71.

65. Morimoto A, Tatsumi Y, Deura K, Mizuno S, Ohno Y, Miyamatsu N, et al. Impact of impaired insulin secretion and insulin resistance on the incidence of type 2 diabetes mellitus in a Japanese population: the Saku Study. Diabetologia. 2013;56(8):1671-9.

66. Gastaldelli A, Gaggini M, DeFronzo RA. Role of adipose tissue insulin resistance in the natural history of type 2 diabetes: results from the San Antonio metabolism study. Diabetes. 2017;66:815-22.

67. Costa A, Rios M, Casamitjana R, Conget I. High prevalence of abnormal glucose tolerance and metabolic disturbances in first degree relatives of NIDDM patients: a study in Catalonia, a Mediterranean community. Diabetes Res Clin Pract. 1998:41(3):191-6.

68. Weyer C, Hanson RL, Tataranni PA, Bogardus C, Pratley RE. A high fasting plasma insulin concentration predicts type 2 diabetes independent of insulin resistance: evidence for a pathogenic role of relative hyperinsulinemia. Diabetes. 2000;49:2094-101.

69. Pontiroli AE, Monti LD, Costa S, Sandoli PE, Pizzini A, Solerte SB. In middleaged siblings of patients with type 2 diabetes mellitus normal glucose tolerance is associated with insulin resistance and with increased insulin secretion: the SPIDER Study. Eur J Endocrinol. 2000;143:681-6.

70. Tripathi D, Carlsson M, Isomaa B. Insulin secretion and insulin sensitivity in relation to glucose tolerance: lessons from the Botnia study. Diabetes. 2000; 49:975-80.

71. Axelsen M, Smith U, Eriksson JW, Taskinen MR, Jansson PA. Postprandial hypertriglyceridemia and insulin resistance in normoglycemic first-degree relatives of patients with type 2 diabetes. Ann Intern Med. 1999;131(1):2731.

72. Cederberg H, Stancakova A, Kuusisto J, Laakso M, Smith U. Family history of type 2 diabetes increases the risk of both obesity and its complications: is type 2 diabetes a disease of inappropriate lipid storage? J Intern Med. 2015; 277(5):540-51.

73. Moon JH, Roh E, Oh TJ, Kim KM, Moon JH, Lim S, et al. Increased risk of metabolic disorders in healthy young adults with family history of diabetes: from the Korea National Health and Nutrition Survey. Diabetol Metab Syndr. 2017;9:16.

74. Chen GW, Li L, Dai F, Li XJ, Xu XX, Fan JG. Prevalence of and risk factors for Type 2 diabetes mellitus in hyperlipidemia in China. Med Sci Monitor. 2015; 21:2476-84

75. Lee $\mathrm{Y}-\mathrm{H}$, Shin M-H, Nam H-S, Park K-S, Choi S-W, Ryu S-W, et al. Effect of family history of diabetes on haemoglobin A1c levels among individuals with and without diabetes. The Dong-gu Study. Yonsei Med J. 2018;59(1): 92-100.

76. Sung KC, Rhee EJ. Glycated haemoglobin as a predictor for metabolic syndrome in non-diabetic Korean adults. Diabet Med. 2007:24:848-54

77. Dagogo-Jack S. Pitfalls in the use of $\mathrm{HbA1C}$ as a diagnostic test: the ethnic conundrum. Nat Rev Endocrinol. 2010;6:589-93.

78. Mohan V, Vijayachandrika V, Gokulakrishnan K, Anjana RM, Ganesan A, Weber MB, et al. A1C cut points to define various glucose intolerance groups in Asian Indians. Diabetes Care. 2010;33:515-9.

79. Osei K, Rhinesmith S, Gaillard T, Schuster D. Is glycosylated hemoglobin A1C a surrogate for metabolic syndrome in non-diabetic, first-degree relatives of African-American patients with type 2 diabetes? J Clin Endocrinol Metab. 2003:88:4596-601.

80. Leite SA, Anderson RL, Kendall DM, Monk AM, Bergenstal RM. A1C predicts type 2 diabetes and impaired glucose tolerance in a population at risk: the community diabetes prevention project. Diabetol Metab Syndr. 2009;1:5.

81. Selvin E, Steffes MW, Zhu H, Anjana RM, Ganesan A, Pankow J, et al. Glycated hemoglobin, diabetes, and cardiovascular risk in non-diabetic adults. N Engl J Med. 2010;362:800-11.

82. Bonora E, Targher G, Kiechl S, Bonadonna RC, Mayr A, Willeit J, et al. Highnormal $\mathrm{HbA} 1 \mathrm{C}$ is a strong predictor of type 2 diabetes in the general population. Diabetes Care. 2011;34:1038-40.

\section{Publisher's Note}

Springer Nature remains neutral with regard to jurisdictional claims in published maps and institutional affiliations.

Ready to submit your research? Choose BMC and benefit from:

- fast, convenient online submission

- thorough peer review by experienced researchers in your field

- rapid publication on acceptance

- support for research data, including large and complex data types

- gold Open Access which fosters wider collaboration and increased citations

- maximum visibility for your research: over $100 \mathrm{M}$ website views per year

At $\mathrm{BMC}$, research is always in progress.

Learn more biomedcentral.com/submission 